\title{
Internet of Religion: Islam and New Media Construction of Religious Movements in Indonesia
}

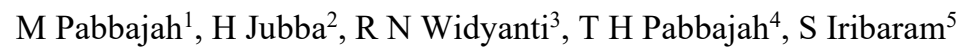 \\ Universitas Teknologi Yogyakarta, Jl. Siliwangi, 163, Sleman, Yogyakarta ${ }^{1}$ \\ Islamic Politics-Political Scinece, Universitas Muhammadiyah Yogyakarta, ${ }^{2}$ \\ Universitas Teknologi Yogyakarta, Jl. Siliwangi, 163, Sleman, Yogyakarta ${ }^{3}$ \\ Institut Agama Islam Negeri Parepare, Jl. Amal Bhakti No.8, Bukit Harapan,Parepare, \\ Sulawesi Selatan 91131Sulawesi Selatan ${ }^{4}$ \\ Institus Agama Islam Negeri Fattahul Muluk Jayapura, Papua ${ }^{5}$ \\ \{mustaqim_pabbajah@uty.ac.id ${ }^{1}$, hasse.j@uy.ac.id², ratri.nurina@uty.ac.id ${ }^{3}$, \\ taufiqpabbajah90@yahoo.com ${ }^{4}$,damiribar@yahoo.co.id ${ }^{5}$ \}
}

\begin{abstract}
Religious mediation has become a new discourse in today's digital industry society. This is inseparable from various forms of online media that can be accessed openly through new media, including the consumption of religious teachings and understanding. This paper discusses the construction of new media on the dynamics of religious movements in Indonesia, by observing the use of social media such as Facebook, Instagram and Twitter are consumed massively in the middle of religious communities in Indonesia. This writing is based on observations with a netnographic approach in online media with qualitative descriptive research methods. This paper shows that the intensity of moderate religious movements taking place in the digital age has increased. This is related to the intensity of new consumption media that construct the realization of religious movements that give color to the online media. Also, information disclosure and calls for mass mobilization through new media have implications in a massive religious movement.
\end{abstract}

Keywords: Construction, New Media, Religious Movements.

\section{Introduction}

The development of information technology in the digital era today is marked by the more intense penetration of new media in various aspects of economic, political, cultural and social life, and religion. This phenomenon emphasizes the change in communication patterns from face to face communication to new media communication, from conventional media models to digitalization communication, from scriptural to digital by using a variety of contemporary social media. With the rapid penetration of digital technology, the internet seems to be a new fertile field for anyone who can see and master the new media or channel. Indonesia is said to have internet penetration of 143.26 million people out of a total population of 262 million people in the survey results of Indonesian Internet Service Provider Association (APJII) in 2017 [1]. Moreover, in line with infrastructure support, and government policies and openness 
which then facilitate access to the internet and electronic device clans, inside content of digital and online-based media, it actually brings up online media, that even in some articles, are called new media in society [2].

Social media as one of the new media in the world of information technology and communication now brings a change in society, including a role in stimulating religious movements. The development of social media makes a pattern of community behavior experience a shift in both culture, ethics and religious norms that have already existed. Indonesia, with its big number of population and with its diverse ethnic, racial and religious cultures, has a lot of potential dynamics of religious social movements. The rise of religious movements is not inseparable from the intensity of the use of social media in various forms and facilities that gives more easy access to the wider community. This condition certainly accelerates the sharing and dissemination of religious knowledge and understanding that can trigger massive and open mobility in society.

The pattern and dynamics of the religious movement are spreading rapidly as the more intensive penetration of new media in people's lives in Indonesia. New media made public consumption openly and transparently in daily life. One of the most intense new media used is social media. This is because social media is able to bring religious emotions and psychological closeness to its users so that they are bound to one another. This is what makes social media like Facebook, Instagram, Twitter and so on are said to be social media communicating in an open manner, free and widest in the world. In addition, the Global Monitor survey was quoted by Prihadi said that Indonesia became the country with the biggest Facebook users in the continents of Asia and Australia (www.techno.okezone.com). The data indicate that social media has great potential that can be used as a communication and indoctrination channel of various religious movements that developed lately.

The purpose of this paper is to examine how consumption of new media has implications for religious movements and religious life in Indonesia, especially concerning the three the following questions: (1) how does the religious movement in the digital era now take place; (2) how is the process of new media construction of religious movements in Indonesia; and (3) what are the implications of the construction of new media on the dynamics of religious movements in Indonesia. These three questions are examined by looking at a number of cases that occur in the various discourse on new media relations and religious movements on the Internet.

This paper is based on an assumption that new media has important implications in creating the dynamics of religious movements in Indonesia. The rapid flow of information and religious literacy from actual space to virtual space has constructed understanding and religious ideology. This assumption will be tested by looking at cases that arise in using new media to call for a mass mobilization of religious movements in Indonesia.

\section{Methods}

The method used in this research is descriptive qualitative. This research explains reality as it is without being changed [3]. It aims to explain the reality of religious movements constructed through new media that is openly accessed by the public. This method approaches social phenomena which specifically looks at why people behave and act as they do [4].

In addition, this qualitative research refers to Hammersley and Atkinson [5], who study data that are obtained for the development of concepts related to the construction of new media to the movement religious. Data is collected through netnographic studies, namely the 
process of collecting data by using the internet [6]. Researchers make observations on the media social like Facebook, Instagram, and Twitter. Analysis of the data in this study is in accordance with Sugiyono's explanation [7], consisting of the process of data collection, data reduction, data presentation, conclusions, and verification.

\section{Result and Discussion}

\section{New Media and Religion in Digital Spaces}

The shift in the pattern of religious studies in the context of this changing digital era has begun by showing how religion experienced mediation that changes the way of thinking about religion from empirical reality into virtual reality [8]. The use of the internet has also been seen as the opening of a new democratic space that allows the public to be involved in the formatting meaning of religious reality [9]-[13]. The public in the new media era has become a subject that can develop a critical attitude in giving meaning and truth to religion. In addition, the public has also manipulated or abused new space media for political propaganda that creates religious conflicts [9];[14]. The character of new media in displaying religious movements like Islam as a religion needs to get a more thorough discussion. The term "New Media" has appeared and become the term used to distinguish it from "old media". This is due to technological developments accepted by a society which in turn leads to a change or transformation which should have been done by a media entity. Here, the line between new media and old media is difficult to determine certainly because it depends on personal perspective [15]. However, the definition of new media itself is presented by Pratt (2000) by combining what is commonly known as multimedia which is literally a convergence of text, sound, and images in the same media that are closely related to the CD-ROM delivery system [16].

Before the advent of new media, print media had been a primadonna due to the validity and quality presented. They are then slowly shifted by changes in the behavior of people who are increasingly enjoying new media offerings. It is mentioned in Nurkinan [17], that media that utilize internet technology, namely social media, make presentation able to give more varied information such as additional photos and videos and make the public able to actively participate through suggestions and criticisms for the government on everything that upsets the citizens. More people use media that supports internet access [1], naturally rise a disruptive phenomenon. The phenomenon is specifically related to the business models of print media industry entities [18]. With their existence, new media and technology are able to produce new possibilities for communication, cultural expression, and daily ways of living of people [19]. In addition, new media also provides a much officially stronger form of social control together with techniques of indoctrination and manipulation which are subtly hidden [19].

The attention to the presence of online media that make this new media gets specific attention has been seen from several studies that associate new media with the existence of conventional media [20] or research specifically conducted to compare online media to printed media or newspaper [21]. It goes on to any research on online media that has a broad influence on the study of social aspects [22]. The research discusses the influence of print media, in a particular domain (for example religion). Printed media are seen as media that do not attract much attention to readers except certain circles because of the mainstream information and entertainment community through television [23]. The process of digitization and internet 
penetration led to the acceleration of the development of online media and in turn they lead to disruption technology that challenges the conventional printed media business model.

However, Christensen in Karimi and Walter [24] points out that this is related to the problem lies in the business model, not the technology problem. Hence, it hints that ideological changes in printed media should be viewed as aspects of business, company's profit, and loss when they adopt new technologies in their products and services. Pawito [18] in his article explains the concept of media ideology as a concept closely related to the belief system (believe system), the principle of ideas (basic way of thinking), outside world views (worldviews) and values (values) carried by media that are delivered to the wider community through various forms of packages such as news, advertisements and so on.

\section{The Existence of Online Media Changes New Color of Religions}

The use of online media is indeed more popular than the use of print media because the use of the internet in online media can facilitate users to access and contribute ideas and opinions without any limitation. It is proven on the decline in accessing and printing in American print media today [25]. The existing mass media such as television, radio, and newspapers used to function as the main information media in disseminating information from a company to the public but today the advent of online media makes drastic changes to the media landscape in the world. This evolution has expanded and it also expanded access to information for the public without space and time limits [26].

The media landscape changes rapidly over time with the growth of the internet. It leads to the emergence of a number of new media organizations that opposed traditional media and it has gained a significant audience for their environmental content. In western countries, the advanced countries namely the United States and European Countries (France, Germany, Spain and the United Kingdom), there are important variations in the pace and nature of the changing media landscape because of technological differences, national specificities, and cultural variations. For example, England and Germany have strong public sectors and private media heritage. However, in UK private media sectors are under more pressure from digital players than in Germany. Digital news media is born generally more prominent in Indonesia, Spain, and France, whose heritage news media is relatively weak. Meanwhile, in the US, they stand out because the US has very weak public sector media but a strong private sector that is challenged by more digital-born players [27].

The emergence of the internet has, in turn, led to the rise of the ability to practice online religion. This can be seen in Bunt's explanation [28], which says that the internet allows events in public spaces to be rumored through social media, including the mention of religion, symbols, and language. From this description, it suggests that activity on the internet-based media is an extension of real activity. Furthermore, Helland [29], provides boundaries of online religion where people can act without restrictions on freedom and interactivity and online religion (in the media) is only a tool for providing religious information. It does not support interaction. Desacralization is seen in the translation of Helland. It describes the different perceptions of the online framework that provides statements to read or pronounce and 'click' mouse as an icon in the online religion. They are considered to be equal to performative needs in real religious actions. This matter indicates that the value of religiosity, when exposed to technology, is adopted as an extension of religious interaction space, but there are also those who consider that similarity is deep in online media is only a means of disseminating information and when they want to practice the value of religion, they need a dedication in the real world appreciation. 


\section{Islam and New Media Construction of Religious Movements}

In the life of Indonesian people, various religious social movements have taken place in several centuries. The Indonesian government basically encourages openness in response to the efforts of religious organizations to accumulate social capital. This reflects the importance of religious values in many aspects of public life, a situation which is also seen in the protection of religious freedom in the national constitution [30]; [31]. As seen in Turkey, the socio-religious movement and it's growth highlight that interfaith dialogue always becomes an important part of religion [32]. The existence of religious movements today is more easily socialized and organized by easier access to social media. In addition, social media has opened the door to the emergence of new thought and creativity on how to organize and plan a political movement and rapid social revolution which have broad influence.

This condition can be seen from the emergence of religious movements through social media. Although it is very diverse in terms of its origin and the specific purpose of its formation, social media make the religious movement have the vision to achieve its same general goals. One fact to support the policy of religious authorities is the emergence of the MUI Fatwa Guards National Movement. Some of such religious movements are not practically political. Some of them tend to be more assertive in expressing their political nature, while others are more patterned religious organization movement and they fight for cultural identity. Various kinds of religious upheaval are also often found to be related to social change with additional things accompanying it including social unrest, mobility, and dissension [31].

Basically, the emergence of social media is expected to be a medium for the creation of broader democratic space. Social networks can be used as a place of a new social movement, as happened in Tunisia, Egypt, Yemen, and Libya. With discourse mobilization in cyberspace, ultimately they moved people to plunge to walk and join the revolutionary movement. In the Indonesian context, social media construction has often taken an important role in voicing the aspirations of the people. One example was the case of Prita Mulyasari with Omni International Hospital. The "Coin for Prita" movement spread quickly through Facebook and Twitter, so it encouraged public support and sympathy for Prita. Then, there was "Lizard vs Crocodile". It was the feud between the KPK and the Police which also became a great debate in social media at that time. The KPK also received support from many parties as a result of information circulating in cyberspace. Another example was the 212 Islamic defense action movement coordinated by the National Movement for Guarding Fatwa - Indonesian Ulama Council (GNPF-MUI) and supported by a number of social organizations (mass organizations), such as the Islamic Defenders Front (FPI).

This movement is getting stronger because it is supported directly by the MUI and its massive dissemination through the media and internet use for political Islam [33]. This fact shows that Indonesian society has become an information society supported by the use of internet media in everyday life. A data survey conducted by Indonesian Internet Service Providers Association [34], shows that in 2016, 129.2 million people (97.4\%), and in 2017 143.26 million people of the total population 262 million of the total internet users in Indonesia made social media a type of the most accessed media platform. The data shows that it was conducted by more than half the population of Indonesia and of course it increases every year. The high use of social media in the community, viewed from the data, potentially becomes a vehicle for political actors and community organization figures to mobilize the masses in certain social movements to achieve the objectives of the action. 
Besides, this is also supported by the condition of Indonesia as a democratic country that provides space for the community to express their aspirations. In this context, social media can also be a means of forming public opinion [34]. This confirms that the existence of New Media has not only brought a basic change in the social, political, economic, and cultural fields, but also brought a change in aspects of thought, fatwas, and religious practices, and relationships on the basis of religious norms.

This tendency is a challenge and at the same time a hope for religions [35]. In Islam, the idea of authority is certainly very problematic because of the assumption that the owner of the singular authority is Allah as contained in the Holy Qur'an. Following to the definition then the authority owners in Islam are those who have the ability to invite and directs to act in accordance with the messages of Islam in the Qur'an. Those who are considered to have authority could be an ulama (religious leader in Islam) in person or ulama in the association of organizations or institutions that have government legitimacy. Accordingly, traditional authority in Islam is in the hands of the ulama or kyai or cleric. They have legitimate authority and provide an interpretation of the Scriptures to resolve the problems of the people with fatwas issued [36]. Among the very important changes in the construction of new media on religious movement, dynamics are the shifts in religious authority and the patterns of relationships between followers with religious figures or leaders who become role models in daily life.

Previously, religious authority was only owned by the ulama, murshid, religion teachers, cleric, government through the Ministry of Religion, and non-government institutions [37]; [38]. Religious authorities are currently experiencing a shift to new media that seems impersonal and based on information networks (Internet). Everyone can easily access knowledge according to their choice and needs. Someone who needs an answer to a problem does not have to ask the clerics directly. Because religious fatwas are no longer only owned by conventional ulama, but anyone can easily find answers and make decisions based on information available on the media.

In the Middle East, new media potential inspires many people to do civil society movements around the world, including in Western countries, where the new social media begins. The same thing also happens in Indonesia in a little different form, among others, the movement to reject the criminalization of eradication corruption activists and coin collecting movements. More than that, according to its democratic character, new media gives the widest possible space for citizens and everyone to offer ideas, opinions, fatwas to others without limits. Religion fatwas, ijtihad results, political-religious ideology, and the like can be accessed easily by the community freely following the figures who previously became role models [36].

For Muslims, the problem of religious authority is a not simple issue, both on the terminology definition and its implementation in religious life experience. What is actually the problem of Islamic authority may be resolved and does not bring up much interpretation. It is not in the same case as the issue of who owns Islamic authority in context Indonesian nation and state. It is not an exaggeration to say that Indonesia is the most difficult Muslim country to answer the question about who actually is the sole owner of religious authority to regulate and give direction to Muslims to translate Islamic messages in life. Moreover, in a new mediabased society as explained earlier where the public is increasingly scattered both socially and intellectually, it can hardly determine who owns religious authority and what the limits are. In other Muslim countries, this problem can be answered by pointing the finger to the state/government or the fatwa institution appointed and elected, such as in Malaysia, Brunei, or in the Middle East. 
New media itself, has changed the face of religion throughout the world, with the openness of exposed press release. From there, the virtual world becomes "real life" which also applies to religion [39]. With the internet, Segerberg and Bennet argue that the role of social media channels in the community grows so fast that they enter the protests phase in the sense that they have become part of the tools of social and political activism. And also, social media comes from social control and manipulation by political forces, companies, and strong media [9]. Besides, the internet also brings its influence in the interpretation of Islam by pro-jihadist platforms and organizations with the emergence of the post-al-Qaeda platform related to the Islamic state. Jihad-oriented campaign by Al-Qaeda's network is influenced by the internet, which has made a significant difference to bring forth Islamic movements and radicalization, where jihadi networks and organizations have been using new media as a tool for logistics and publicity for years [28].

\section{Conclusion}

Media and society cannot be separated anymore in the current digital era. The development of media that is quickly followed by massive public consumption certainly influences religious understanding from actual to virtual. These dynamics continue to roll amid the acceleration of new media-based information technology. How to create the right atmosphere to respond to religious passion is to keep moving within the frame of diversity and civilization. This paper underlines three things in observing the construction of new media implication to the dynamics of religious movements. First, the continuity of current religious movements can't be separated from the intensity of the wide and open use of new media by the public. Second, the increasingly quick-shifting patterns of a transformation of religious understanding through new media construct an increasingly rapid and widespread intensity of religious movements. The tendency of new media construction has played an important role in accelerating and expanding unavoidable and irresistible social, cultural and political changes on a national scale. Third, the implications of new media construction change the face to face system of the holders of religious authority in the transfer of religious understanding to online media. Likewise, this phenomenon shows a shift pattern of interaction between religious leaders and followers.

\section{References}

[1] APJII, Infografis Penetrasi dan Perilaku Pengguna Internet Indonesia Survey (2017). Asosiasi Penyelenggara Jasa Internet Indonesia, 2017.

[2] APJII, “Asosiasi Penyelenggara Jasa Internet Indonesia,” 2018.

[3] L. Moeleong, Metodologi Penelitian Kualitatif Moleong Edisi Revisi. Bandung: Remaja Rosda, 2017.

[4] K. Hancock, B., Ockleford, E., \& Windridge, "An introduction to qualitative research. Yorkshire, United Kingdom:,” Natl. Inst. Heal. Res. Yorksh. Humber, 2009.

[5] P. Hammersley, M., \& Atkinson, Ethnography: Principles in practice. London, United Kingdom: Routledge, 2017.

[6] R. V. Kozinet, Netnography: Doing ethnographic research online. Singapore: SAGE Publications, 2010.

[7] Sugiyono, Metode Penelitian Kualitatif, Kuantitatif dan R\&D. Bandung: Alfabeta, 2016.

[8] I. Abdullah, "Di Bawah Bayang-bayang Media: Kodifikasi, Divergensi, dan Kooptasi Agama di Era Internet," Sabda, vol. 12, no. 2, pp. 116-121, 2017. 
[9] A. Al-Rawi, "Online reactions to the Muhammad cartoons: YouTube and the virtual Ummah,” J. Sci. Study Relig., vol. 54, no. 2, pp. 261-276, 2015.

[10] M. Poster, "Cyber Democracy: The Internet and the Public Sphere," in David Trend (ed.). Reading Digital Culture, Oxford: Blackwell Publisher, 2001.

[11] P. Dahlgren, Media and Political Engagement: Citizens, Communications and Democracy. Cambridge: Cambridge University Press, 2009.

[12] D. Von Mucke, "Authority, Authorship, and Audience: Enlightenment Model for a Critical Public," Representation, vol. III, no. 1, pp. 60-87, 2010.

[13] et al. Aguilar, G.K., "Communicating Mixed Messages about Religion through Memes," Inf. Commun. Soc., vol. 20, no. 10, pp. 1498-1520, 2017, doi: DOI: 10.1080/1369118X.2016.1229004.

[14] G. Evolvi, "Hate in a Tweet: Exploring Internet-Based Islamophobic Discourses," Religions, vol. 9, no. 10, p. 307, 2018, doi: doi:10.3390/re19100307.

[15] J. R. Situmorang, "Pemanfaatan internet sebagai new media dalam bidang politik, bisnis, pendidikan dan sosial budaya," J. Adm. Bisnis, vol. 8, no. 1, 2018.

[16] A. C. Pratt, New media, the new economy and new spaces, vol. 31, no. 4. 2000.

[17] Nurkinan, "Dampak Media Online Terhadap Perkembangan Media Konvensional," J. Polit. Indones., vol. 2, no. 2, 2017.

[18] Pawito, "Meneliti Ideologi Media: Catatan Singkat," J. Komun. PROFETIK. Univ. Sebel. Maret Surakarta, vol. 7, no. 1, 2014.

[19] D. Kellner, "Intellectuals and new technologies," Media, Cult. Soc., vol. 17, no. 3, pp. 427-448, 1995.

[20] P. Rianto, "Media Baru, Visi Khalayak Aktif Dan Urgensi Literasi Media," Jurnal Komunikasi, vol. 1, no. 2. Universitas Islam Indonesia, pp. 90-96, 2016.

[21] K. S. and E. L. De Waal, Ester, "Online newspapers: A substitute or complement for print newspapers and other information channels?," Communication, vol. 30, no. 1, pp. 55-72, 2005, doi: DOI: 10.1515/com.

[22] C. L. Byrne, "Online Ideology: A Comparison of Website Communication and Media Use," J. Comput. Commun., vol. 18, pp. 137-153, 2013, doi: DOI: 10.1111 /jcc4.12003.

[23] R. el. Ishaq., "Dakwah di Tengah Industrialisasi Media,” J. Komun. Islam, vol. 3, no. 1, 2013, doi: ISBN 2088-6314.

[24] J. and Z. W. Karimi, "Corporate Entrepreneurship, Disruptive Business Model Innovation Adoption, and Its Performance: The Case of the Newspaper Industry," Long Range Plann., vol. 49, pp. 342-360, 2016, doi: DOI: 10.1016/j.lrp.2015.09.004.

[25] A. Cacciatore, M. A., Anderson, A. A., Choi, D.-H., Brossard, D., Scheufele, D. A., Liang, X., Dudo, "Coverage of emerging technologies: A comparison between print and online media," New Media Soc., vol. 14, no. 6, pp. 1039-1059, 2012, doi: doi:10.1177/1461444812439061.

[26] A. S. F. Ho, S. S., Leong, A. D., Looi, J., \& Chuah, "Online, offline, or word-ofmouth? Complementary media usage patterns and credibility perceptions of nuclear energy information in Southeast Asia," Energy Res. Soc. Sci., vol. 48, pp. 46-56, doi: doi:10.1016.

[27] M. S. Painter, J., Kristiansen, S., \& Schäfer, "How 'Digital-born' media cover climate change in comparison to legacy media: A case study of the COP 21 summit in Paris," Glob. Environ. Chang., vol. 48, pp. 1-10, 2018, doi: doi:101016/j.gloenvcha.2017.11.003.

[28] G. R. Bunt, Hashtag Islam: How Cyber-Islamic Environments are Transforming 
Religious Authority. UNC Press Books, 2018.

[29] C. Helland, "Online religion as lived religion. Methodological issues in the study of religious participation on the internet," Online-heidelb. J. Relig. Internet, 2005.

[30] R. Permani, "The Presence of Religious Organisations, Religious Attendance, and Earnings: Evidence from Indonesia,” J. Socio. Econ., vol. 40, no. 3, pp. 247-258, 2011, doi: doi:10.1016/j.socec.2011.01.006.

[31] M. et. al. Pabbajah, "Contested Socio-Religious Reality: An-Nadzir, a NonMainstream Islamic Movement in Indonesia." pp. 71-78, 2019, doi: doi.org/10.18848/2154-8633/CGP/v09i02/.

[32] B. Balci, "Situating the Gülen Movement in France and in Europe," Polit. Relig. Ideol., vol. 19, no. 1, pp. 69-80, 2018, doi: doi:10.1080/21567689.2018.1453262.

[33] V. Falco, C., \& Rotondi, "Political Islam, Internet Use and Willingness to Migrate: Evidence from the Arab Barometer," Peace Econ. Peace Sci. Public Policy, 2016.

[34] APJII, "Infografis Penetrasi dan Perilaku Pengguna Internet Indonesia Survey (2016)," Asos. Penyelenggara Jasa Internet Indones., 2016.

[35] H. A. n. . Teusner, Paul Emerson dan Cambell, "Religious Authority in the Age of the Internet."

[36] M. Jinan, "Intervensi New Media dan Impersonalisasi Otoritas Keagamaan di Indonesia," J. Komun. Islam, vol. 3, no. 2, 2013.

[37] A. Burhanudin, Jajat, \& Baedhowi, "Transformasi Otori- tas Keagamaan: Pengalaman Islam Indonesia, Gramedia Pusta- ka Utama bekerjasama dengan PPIM, UIN Jakarta dan Basic Education Project," Depag, Jakarta, 2003.

[38] Zulkifli, "The Ulama, Religious Authority and Recognition in Indonesia," in Kumpulan Makalah ACIS X di Samarinda, 2010.

[39] L. Dawson, "Researching Religion in Cyberspace: Issues and Strategies," in Religion on the Internet: Research Prospects and Promises, Religion and the Social Order, ed Jeffery Hadden and Douglas Cowan, vol. 8, New York: JAI Press, 2001. 